\title{
Anti-hyperlipidemic and anti-diabetic evaluation of ethanolic leaf extract of Catharanthus roseus alone and in combination therapy
}

\author{
Khadija Azam', Muhammad Adil Rasheed ${ }^{\circledR 1}$, \\ Muhammad Ovais Omer ${ }^{1}$, Imran Altaf ${ }^{2}$, Amina Akhlaq ${ }^{1}$ \\ ${ }^{1}$ Department of Pharmacology \& Toxicology University of Veterinary and \\ Animal Sciences Lahore, Punjab Pakistan, ${ }^{2}$ Department of Microbiology Uni \\ versity Of Veterinary and Animal Sciences Lahore, Punjab Pakistan
}

\begin{abstract}
The use of plants in disease treatment is cost effective and relatively safe. This study was designed to investigate anti-hyperlipidemic and anti-diabetic activity of ethanolic leaf extract of Catharanthus roseus alone and in combination therapy in hyperlipidemic \& diabetic mice. Eight groups comprising five mice each were used. Group A was hyperlipidemic control, group B, C, D received atorvastatin $(20 \mathrm{mg} / \mathrm{kg})$, leaf extract $(200 \mathrm{mg} / \mathrm{kg})$ and leaf extract in combination with atorvastatin $(200 \mathrm{mg} / \mathrm{kg}$ and $20 \mathrm{mg} / \mathrm{kg}$ ) orally for 15 days. Group E was diabetic control. Group F, G, H received sitagliptin (40 mg/kg), leaf extract $(200 \mathrm{mg} / \mathrm{kg})$ and extract in combination with sitagliptin $(200 \mathrm{mg} / \mathrm{kg}$ and $40 \mathrm{mg} / \mathrm{kg})$ orally for 7 days. Blood cholesterol levels were measured at $1^{\text {st }}, 5^{\text {th }}, 10^{\text {th }}$ and $15^{\text {th }}$ day and fasting blood sugar levels were measured at 2, 12, 24, 72 and 168 hours during treatment. One-way ANOVA with tukeykramer multiple comparison test was used. The chemical characterization of ethanolic extract of Catharanthus roseus leaves showed presence of alkaloids, saponins, tannins and flavonoids. Ethanolic extract of Catharanthus roseus has significant anti-hyperlipidemic \& anti-diabetic effects $(\mathrm{p}<0.05$, $\mathrm{p}<0.01$ ) when compared with control but had not cause significantly increase in anti-hyperlipidemic effects of atorvastatin. While significantly increased the antidiabetic effect of sitagliptin $(p<0.05)$.
\end{abstract}

Key words: Catharanthus roseus leaf extract. Hyperlipidemia. Anti-diabetic activity. Fasting blood sugar. Blood cholesterol levels.

\section{INTRODUCTION}

According to World Health Organization $80 \%$ of population depend on traditional medicines derived from plants. Traditional medicines have better safety profile and cost effectiveness as compare to conventional drugs (Sasidharan et al., 2011). Chemical constituents obtained from secondary metabolites of plants play a key role to cure different ailments (Al-Snafi 2015). Use of herbs and plant extracts to cure different diseases has traditional

\footnotetext{
*Correspondence: M. A. Rasheed. Department of Pharmacology \& Toxicology. University of Veterinary and Animal Sciences. 54000, Lahore, Pakistan. Phone: +923218390727. Email: dr_aadil@uvas.edu.pk
}

value. Use of medicinal plants in early civilization of China \& India is documented (Howes, Houghton, 2003).

Different synthetic drugs are used either alone or in combination to treat hyperlipidemia and hyperglycemia. These drugs have side effects (Meliani et al., 2011). Diabetes is a metabolic disorder which impairs either secretion of insulin or its action, sometimes it may affect both secretion of insulin and action of insulin (Eddouks et al., 2017). Hyperlipidemia is the major complication of diabetes caused by disruption in lipid metabolism (Fox et al., 2015). Increase in blood cholesterol is responsible for progression of different complications (Machaba et al., 2014). Heart diseases and atherosclerosis events are caused by increased in cholesterol, triglycerides. LDL 
accumulation in artery walls results in progression of atherosclerosis (Duraipandiyan et al., 2016).

Hyperlipidemia and diabetes are both considered as major diseases. For the treatment of diabetes and hyperlipidemia many drugs are present but commercial drugs are toxic and have more side effects. Latest research showed that herbal medicines are more safe for treating diabetes and hyperlipidemia than the commercially available drugs used to treat diabetes and hyperlipidemia (Bahmani et al., 2015).

Catharanthus roseus is an ever blooming herb belongs to family Apocyanaceae also known as sadabahar which means "Always in bloom" (Tolambiya, Mathur, 2016). It is very famous plant for its medicinal activities all over the world. The alkaloids of Catharanthus roseus are used in cancer, diabetes, hypertension and hyperlipidemia. The two main constituents of Catharanthus roseus are alkaloids and tannins. Leaf extract of Catharanthus roseus showed significant effect on lipid profile and increased the insulin sensitivity towards the organs (Balaji 2014). The objective of this research was to investigate anti-hyperlipidemic \& antidiabetic activity of Catharanthus roseus ethanol leaves extract in combination therapy.

\section{MATERIAL AND METHODS}

\section{Plant collection and extract preparation}

Catharanthus roseus leaves were collected from fields of Punjab province (Sialkot, Pakistan). The plant was identified from the Herbarium Botany Department of Government College University (GCU) Lahore and a voucher specimen GC.Herb.Bot.3454 has been taken for record. The collected leaves were washed and shade dried. The leaves were dried. Electric blender machine was used to grind the leaves. The powdered leaves were extracted in ethanol solvent $(1000 \mathrm{~mL})$ by using Soxhlet apparatus. The extract was concentrated by using rotary evaporator at reduced pressure and further dried in the oven then kept in refrigerator.

\section{Chemical characterization of ethanolic extract of Catharanthus roseus leaves}

The chemical characterization of ethanolic extract of Catharanthus roseus leaves was performed for the determination of alkaloids, flavonoids, saponins and tannins (Parekh, Chanda, 2007).

\section{Wagner's test}

This test was performed for alkaloids. $1.27 \mathrm{~g}$ of Iodine and $2 \mathrm{~g}$ of KI were first dissolved in distilled water $(5 \mathrm{~mL})$ and then make up volume upto $100 \mathrm{~mL}$ with distilled water. $1 \mathrm{~mL}$ of solution was added with $2 \mathrm{~g}$ of extract. The change in color of solution was observed.

\section{Foam test}

This test was used for saponins. The $1.0 \mathrm{mg}$ ethanolic extract was taken in test tube and was shaken with small amount of sodium bicarbonate and water vigorously. The change in color of solution was observed.

\section{Potassium dichromate test}

This test was used for tannins determination. A $2.0 \mathrm{mg}$ of potassium dichromate was dissolved in distilled water and 1 gram of extract was added. The change in color of solution was observed.

\section{Ferric chloride test}

This test was used for flavonoids. The 3 drops of ferric chloride solution were added to the extract solution and change in color of solution was observed.

\section{Experimental protocols}

Forty male albino mice of $25 \mathrm{~g}$ were taken and kept in the animal shed of Department of Pharmacology and Toxicology. The mice were provided food and water ad-libitum. The experimental procedure used in this study was approved by Ethical Committee of University of veterinary and animal sciences, Lahore. Mice were divided into eight groups. The anti-hyperlipidemic activity of ethanolic extract of Catharanthus roseus leaves was evaluated in groups A-D. The group A was kept as hyperlipidemic control, Group B was administered atorvastatin $20 \mathrm{mg} / \mathrm{kg}$ orally, group C was administered ethanolic extract of Catharanthus roseus leaves at dose of $200 \mathrm{mg} / \mathrm{kg}$ orally, group D was administered ethanolic extract at the dose of $200 \mathrm{mg} / \mathrm{kg}$ in combination with atorvastatin $20 \mathrm{mg} / \mathrm{kg}$ and group E was kept as diabetic control. The treatment was continued for 15 days. The anti-hyperlipidemic activity of ethanolic extract of Catharanthus roseus leaves was evaluated in groups E-H. The group E was 
kept as diabetic control, while group $\mathrm{F}$ was administered with sitagliptin at dose of $40 \mathrm{mg} / \mathrm{kg}$ orally, group $\mathrm{G}$ was administered with ethanolic extract of Catharanthus roseus leaves at dose of $200 \mathrm{mg} / \mathrm{kg}$ orally and group $\mathrm{H}$ was administered with ethanolic extract $200 \mathrm{mg} / \mathrm{kg}$ in combination with sitagliptin $40 \mathrm{mg} / \mathrm{kg}$ orally. The treatment was continued for 7 days.

\section{Induction of hyperlipidemia}

Blood cholesterol levels of mice from all groups were determined before the induction of hyperlipidemia. Hyperlipidemia was induced by giving cholesterol powder $(400 \mathrm{mg} / \mathrm{kg})$ orally. The suspension of cholesterol powder was administered to mice for period of 15 days then treatment was started after 5 days of relaxation period.

\section{Induction of diabetes}

Fasting blood glucose levels of mice were determined before diabetes induction. Single $i / p$ injection of Alloxan $(75 \mathrm{mg} / \mathrm{kg})$ was given to induce Type-2 diabetes in overnight fasted mice. Diabetes was induced after 2 days of alloxan administration. Mice were considered as diabetic having glucose level more than $250 \mathrm{mg} / \mathrm{kg}$ (Vega-Ávila et al., 2012).

\section{Estimation of Blood cholesterol and glucose levels}

Blood was taken from the tail of mice from groups A-D on $1^{\text {st }}, 5^{\text {th }}, 10^{\text {th }}$ and $15^{\text {th }}$ day during the treatment for the estimation of blood cholesterol levels. BestCheck basic blood glucose monitoring system ${ }^{\circledR}$ by Kapitol, Tiwan was used. For blood glucose levels determination, blood from the tail of mice from groups $\mathrm{E}-\mathrm{H}$ at different time intervals on fasting at 2, 12, 24, 72 and 168 hours during the treatment was taken. Fasting blood glucose levels were determined by using BestCheck basic blood glucose monitoring system ${ }^{\circledR}$ by Kapitol, Tiwan.

\section{Statistical analysis}

Data were analyzed as mean \pm SD. Tukey-kramer multiple comparison test was used. To analyze the data statistically (ANOVA) was used. The results were considered significant at $\mathrm{P}<0.05$ and $\mathrm{P}<0.01$ (Ryan 1960).

\section{RESULTS}

\section{Chemical characterization of ethanolic extract of Catharanthus roseus leaves}

The chemical characterization of ethanolic extract of Catharanthus roseus leaves showed the presence of alkaloids, saponins, tannins and flavonoids. Wagner's test was performed. Dark brown color precipitates indicated the presence of alkaloids. Foam and froth test indicated the presence of saponins. The dark color was observed in potassium dichromate test, which indicated presence of tannins. In ferric chloride test, intense green color was observed; this indicated the presence of flavonoids. Figure 1. 


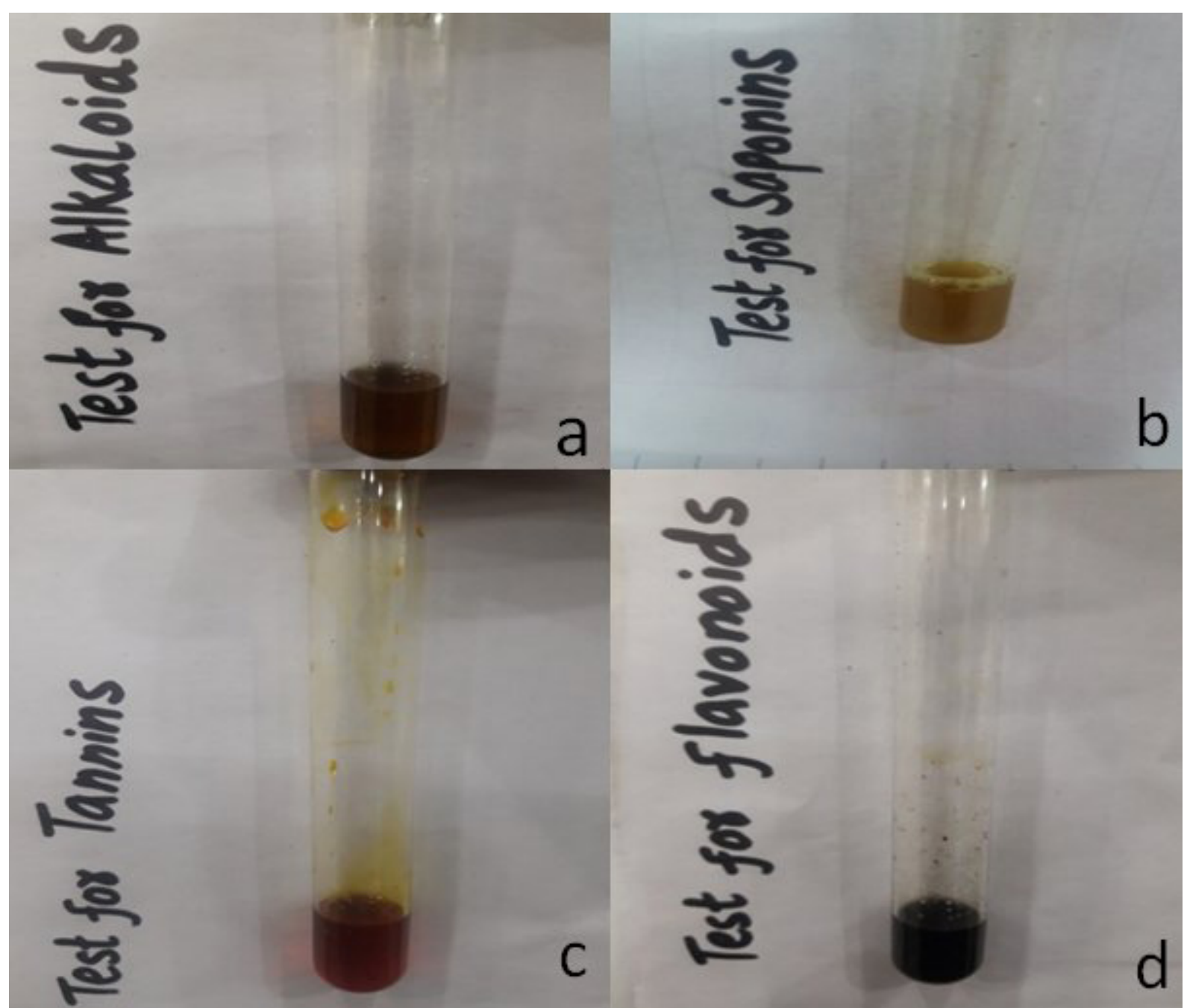

FIGURE 1 - Phytochemical screening of ethanolic extract of Catharanthus roseus leaves Ethanolic extract. a: Wagner's test; dark brown color precipitates indicated for alkaloids b: Foam test; Froth indicated for saponins c: Potassium dichromate test; dark color indicated for tannins. d: Ferric chloride test; Intense green color indicated for flavonoides.

\section{Anti-hyperlipidemic activity of ethanolic leaf extract of Catharanthus roseus}

The mice in group $\mathrm{B}$ and $\mathrm{C}$ treated with atorvastatin and ethanolic extract of Catharanthus roseus leaves exhibited slight decrease $(\mathrm{p}<0.05)$ in cholesterol levels on $1^{\text {st }}$ and $5^{\text {th }}$ day of treatment while a significant decrease $(\mathrm{p}<0.01)$ was seen on $10^{\text {th }}$ and $15^{\text {th }}$ day of treatment, respectively when compared with control group. There no combinational effect was seen in group D of mice treated with ethanolic extract of Catharanthus roseus leaves and atorvastatin. Table I. 
TABLE I - Blood cholesterol levels $(\mathrm{mg} / \mathrm{dL})$ in mice $(\mathrm{n}=5)$ at different time intervals during treatment

\begin{tabular}{lcccccc}
\hline \multirow{2}{*}{ Groups } & $\begin{array}{c}\text { Pre-induction } \\
\text { cholesterol } \\
\text { Levels }\end{array}$ & $\begin{array}{c}\text { Post induction } \\
\text { cholesterol } \\
\text { Levels }\end{array}$ & \multicolumn{3}{c}{ Cholesterol level during treatment (mg/dL) } \\
\cline { 5 - 7 } & $103.60 \pm 2.7$ & $152.0 \pm 3.1$ & $161.60 \pm 4.50$ & $169.40 \pm 4.21$ & $176.20 \pm 2.38$ & $180.20 \pm 4.20$ \\
\hline Group A & $102.80 \pm 3.1$ & $161.60 \pm 4.5$ & $153.00 \pm$ & $136.40 \pm$ & $123.40 \pm$ & $106.20 \pm$ \\
Group B & & & $3.16^{*}$ & $3.57^{*}$ & $2.70^{* *}$ & $3.27^{* *}$ \\
& & & $152.8 \pm$ & $144.20 \pm$ & $131.20 \pm$ & $121.20 \pm$ \\
Group C & $104.60 \pm 3.5$ & $161.0 \pm 3.1$ & $4.20^{*}$ & $4.14^{*}$ & $3.49^{* *}$ & $3.49^{* *}$ \\
& & & $154.20 \pm$ & $144.60 \pm$ & $133.00 \pm$ & $122.00 \pm$ \\
Group D & $105.20 \pm 2.8$ & $160.20 \pm 2.3$ & $3.19^{*}$ & $3.05^{*}$ & $3.16^{* *}$ & $3.16^{* *}$ \\
\hline
\end{tabular}

$* \mathrm{P}<0.05 ; * * \mathrm{P}<0.01$; significant level when compared to the hyperlipidemic control.

Data were analyzed as mean \pm SD. Tukey-kramer multiple comparison test was used. To analyze the data statistically (ANOVA) was used. The results were considered significant at $\mathrm{P}<0.05$ and $\mathrm{P}<0.01$

\section{Anti-diabetic activity of ethanolic leaf extract of Catharanthus roseus}

Mice in group $\mathrm{F}$ and $\mathrm{G}$ treated with sitagliptin and ethanolic extract of Catharanthus roseus leaves exhibited slight decrease $(\mathrm{p}<0.05)$ in fasting blood glucose levels on 2,12 and 24hours of treatment and significant decrease $(\mathrm{p}<0.01)$ was seen on $72 \mathrm{~h}$ and 168 hours of treatment respectively when compared with control group $(\mathrm{p}<0.01)$. The group $\mathrm{H}$ treated with sitagliptin in combination with ethanolic extract of Catharanthus roseus leaves exhibited moderate significant combinational effect by decreasing glucose levels $(\mathrm{p}<0.05)$ on $24 \mathrm{~h}$ and significant decrease $(\mathrm{p}<0.01)$ in glucose levels on $72 \mathrm{~h} \& 168 \mathrm{~h}$ when compared with group $\mathrm{F}$, which was administered sitagliptin alone. Table II.

Table- II - Fa sting blood glucose levels $(\mathrm{mg} / \mathrm{dL})$ in mice $(\mathrm{n}=5)$ at different time intervals during treatment

\begin{tabular}{|c|c|c|c|c|c|c|c|}
\hline \multirow{2}{*}{ Groups } & \multirow{2}{*}{$\begin{array}{c}\text { Pre - } \\
\text { induction } \\
\text { FBG }\end{array}$} & \multirow{2}{*}{$\begin{array}{c}\text { Post- } \\
\text { induction } \\
\text { FBG }\end{array}$} & \multicolumn{5}{|c|}{ Fasting blood glucose during treatment $(\mathrm{mg} / \mathrm{dL})$} \\
\hline & & & $2 \mathrm{~h}$ & $12 \mathrm{~h}$ & $24 \mathrm{~h}$ & $72 \mathrm{~h}$ & $168 \mathrm{~h}$ \\
\hline \multirow{2}{*}{ Group E } & $79.80 \pm$ & $405.00 \pm$ & $416.20 \pm$ & $425.40 \pm$ & $434.80 \pm$ & $456.60 \pm$ & $481.40 \pm$ \\
\hline & 3.19 & 3.16 & 2.38 & 3.57 & 4.38 & 5.72 & 2.70 \\
\hline
\end{tabular}


Table- II - Fa sting blood glucose levels $(\mathrm{mg} / \mathrm{dL})$ in mice $(\mathrm{n}=5)$ at different time intervals during treatment

\begin{tabular}{|c|c|c|c|c|c|c|c|}
\hline \multirow{2}{*}{ Groups } & \multirow{2}{*}{$\begin{array}{c}\text { Pre - } \\
\text { induction } \\
\text { FBG }\end{array}$} & \multirow{2}{*}{$\begin{array}{c}\text { Post- } \\
\text { induction } \\
\text { FBG }\end{array}$} & \multicolumn{5}{|c|}{ Fasting blood glucose during treatment (mg/dL) } \\
\hline & & & $2 \mathrm{~h}$ & $12 \mathrm{~h}$ & $24 \mathrm{~h}$ & $72 \mathrm{~h}$ & $168 \mathrm{~h}$ \\
\hline \multirow{2}{*}{ Group F } & $78.00 \pm$ & $406.80 \pm$ & $314.60 \pm$ & $209.20 \pm$ & $191.40 \pm$ & $171.20 \pm$ & $137.20 \pm$ \\
\hline & 4.12 & 3.11 & $6.58^{*}$ & $7.52^{*}$ & $8.26^{*}$ & $5.11^{* *}$ & $3.96 * *$ \\
\hline \multirow{2}{*}{ Group G } & $76.80 \pm$ & $404.40 \pm$ & $379.60 \pm$ & $217.20 \pm$ & $194.80 \pm$ & $171.00 \pm$ & $139.20 \pm$ \\
\hline & 3.70 & 3.05 & $8.56^{*}$ & $6.22 *$ & $5.35^{*}$ & $4.18^{* *}$ & $4.91 * *$ \\
\hline \multirow{2}{*}{ Group H } & $81.00 \pm$ & $405.60 \pm$ & $316.20 \pm$ & $206.80 \pm$ & $176.80 \pm$ & $150.80 \pm$ & $107.40 \pm$ \\
\hline & 8.80 & 3.43 & $5.63^{*}$ & $6.26 *$ & $3.11^{*} \Delta$ & $6.18^{* *} \Delta \Delta$ & $3.64 * * \Delta \Delta$ \\
\hline
\end{tabular}

$* \mathrm{P}<0.05 ; * * \mathrm{P}<0.01$ significant level when compared to the diabetic control. $\Delta \mathrm{P}<0.05 ; \Delta \Delta \mathrm{P}<0.01$; when compared to standard drug ie, sitagliptin

Data were analyzed as mean \pm SD. Tukey-kramer multiple comparison test was used. To analyze the data statistically (ANOVA) was used. The results were considered significant at $\mathrm{P}<0.05$ and $\mathrm{P}<0.01$

\section{DISCUSSION}

The chemical characterization of ethanolic extract of Catharanthus roseus leaves showed the presence of alkaloids, saponins, tannins and flavonoids. Hisiger (2007) determined the secondary metabolites of Catharanthus roseus which are being used in cancer chemotherapy. The well-known metabolites vinblastine and vincristine were found in Catharanthus roseus. Nasir et al (2016) also reported the presence of phenolic compounds, saponins, tannin, flavonoids and quinines from crude extract of plant. Goswami (2013) found glycosides, alkaloids, phenols, flavonoids, saponins, tannins and amino acids from the ethanolic leaf extract of Catharanthus roseus. Kabesh et al (2015) separated the chemical fractions from aqueous and methanol leaf extracts of Catharanthus roseus by Thin Layer Chromatography (TLC). The fractions were further analyzed with GC-MS. The analysis revealed the presence of saponins phenols and alkaloids (Kabesh et al 2015).

In present study ethanolic leaf extract of Catharanthus roseus (200 $\mathrm{mg} / \mathrm{kg}$ b.w) showed a significant decline in blood cholesterol levels in hyperlipidemic groups. These findings correlate with the Antia and Okokon (2005) who reported the antihyperlipidemic effect of leaf juice of Catharanthus roseus in normal rats. Different concentrations of Catharanthus roseus leaf juice was given to rats as 0.1 $\mathrm{mL} / \mathrm{kg}, 0.5 \mathrm{~mL} / \mathrm{kg}$ and $1 \mathrm{~mL} / \mathrm{kg} /$ day. Treatment was carried out for seven days. Total cholesterol, total TG (triglyceride) and LDL levels were reduced. Reduction in total cholesterol, triglyceride and LDL cholesterol was more seen at high dose $(1 \mathrm{~mL} / \mathrm{kg})$. The result of this also correlates with the Patel et al. (2011) who studied the anti-hyperlipidemic effect of leaf juice of Catharanthus roseus in guinea pigs. High fat diet was given to animals for induction of Hyperlipidemia. The leaf juice of Catharanthus roseus was given to animals after induction of hyperlipidemia, in two different doses 0.5 and $1 \mathrm{~mL} / \mathrm{kg}$. There was a significant reduction in total cholesterol, total triglyceride and LDL cholesterol.

Significant decline in Blood glucose levels of diabetic mice groups treated with ethanolic extract of Catharanthus roseus $200 \mathrm{mg} / \mathrm{kg}$ b.w was observed. The results of this study are similar with Muralidharan (2015) who stated the anti-diabetic effect of Catharanthus roseus in diabetic rats. For induction of diabetes, 
alloxan was given. Leaf extract of Catharanthus roseus was given to diabetic animals. There was significant reduction in glucose level. The findings of this research also correlates with Rasineni and Desireddy (2011) who reported that suspension of Catharanthus roseus leaf powder in water was given to rats for 60 days. Catharanthus roseus suspension showed significant anti-diabetic effect. Research concluded that long term use of catharanthus roseus prevent the insulin resistance in body. So Catharanthus roseus could be used as combination therapy to prevent or manage the insulin resistance in pre-diabetic condition. The findings of this research also correlates with Ohadoma and Michael (2011) who studied anti diabetic effect of methanol leaf extract of Catharanthus roseus in rats. Results of study revealed that significant interaction was seen between metformin and extract combination as compared to the drug alone.

\section{CONCLUSION}

The result of this study revealed that ethanolic extract of Catharanthus roseus leaves has significant anti-hyperlipidemic \& anti-diabetic effect. Antihyperlipidemic effects of ethanolic extract of Catharanthus roseus leaves were not enhanced when administered in combination with atorvastatin. While ethanolic extract of Catharanthus roseus leaves significantly increased the anti-diabetic effects in combination with sitagliptin.

\section{ACKNOWLEDGMENTS}

Authors are grateful to the department of Pharmacology \& Toxicology University of Veterinary and Animal Sciences Lahore Pakistan, for providing laboratory facilities and funds during the conduct of research.

\section{CONFLICT OF INTEREST}

The authors declare no conflict of interest.

\section{REFERENCES}

Al-Snafi AE. Therapeutic properties of medicinal plants: a review of plants with hypolipidemic, hemostatic, fibrinolytic and anticoagulant effects (part 1). Asian J Pharm Sci Technol. 2015,5(4):271-284.
Antia B, Okokon J. Effect of leaf juice of Catharanthus roseus Linn on cholesterol, triglyceride and lipoproteins levels in normal rats. Indian J Pharmacol.2005,37(6):401-402.

Bahmani M, Mirhoseini M, Shirzad H, Sedighi M, Shahinfard, Kopaei MR. A review on promising natural agents effective on hyperlipidemia. J Evid Based Complem Altern Med. 2015,20(3):228-238.

Balaji DH, Versatile. Therapeutic effects of Vinca rosea Linn. Int J Pharm Sci Health Care. 2014,1(4):59-76.

Duraipandiyan V, Al-Dhabi NA, Irudayaraj SS, Sunils C. Hypolipidemic activity of friedelin isolated from Azima tetracantha in hyperlipidemic rats. Rev Bras Farmacog. 2016,26(1):89-93.

Eddouks M, Lemhadri A, Hebi M, Hidani A EL, Zeggwagh NA, Bouhali B EL, et al. Capparis spinosa L. aqueous extract evokes antidiabetic effect in streptozotocin-induced diabetic mice. Avicenna J Phytomed. 2017,7(2):191.

Fox CS, Golden SH, Anderson C, Bray GA, Burke LE, De Boer $\mathrm{IH}$, et al. Update on prevention of cardiovascular disease in adults with type 2 diabetes mellitus in light of recent evidence: a scientific statement from the American Heart Association and the American Diabetes Association. Circulation.2015,38(9):1777-1803.

Goswami S. Preliminary Phytochemical Screening and Standardization of Leaves of Catharanthus roseus(L.). Indian J Res Pharm Biotechno. 2013,1(1):24-27.

Hisiger S, Jolicoeur M. Analysis of Catharanthus roseus alkaloids by HPLC. Phytochem Rev. 2007,6:207-234.

Howes MJ, Houghton PJ. Plants used in Chinese and Indian traditional medicine for improvement of memory and cognitive function. Pharmacol Biochem Behav. 2003,75(3):513-527.

Kabesh K, Senthilkumar P, Ragunathan R, Kumar RR. Phytochemical Analysis of Catharanthus roseus Plant Extract and its Antimicrobial Activity. Int. J. Pure App. Biosci. 2015,3(2):162-172.

Machaba KE, Cobongela SZ, Mosa RA, Oladipupo LA, Djarova TG, Opoku AR. In-vivo anti-hyperlipidemic activity of the triterpene from the stem bark of Protorhus longifolia (Benrh) Engl. Lipids health dis. 2014; 13(1):131-137.

Meliani N, Dib ME, Allali H, Tabti B. Hypoglycaemic effect of Berberis vulgaris $L$. in normal and streptozotocin-induced diabetic rats. Asian Pac J Trop Biomed. 2011,1(6):468-471.

Muralidharan L. Hypoglycemic and biochemical remedies of Cathanthus roseus (Linn) on Alloxan-induced diabetic rat 
and its antioxidant status in rat lenses. Int J Med Res Pharm Sci. 2015,2(1):1-6.

Nisar A, Mamat AS, Hatim MI, Aslam MS, Ahmad MS. Phytochemical and pharmacognostic study of catharnthus roseus using deep eutectic solvents, Int. J. Res. Ayurveda Pharm. 2016,7(Suppl 3):141-146.

Ohadoma S, Michael H.. Effects of co-administration of methanol leaf extract of Catharanthus roseus on the hypoglycemic activity of metformin and glibenclamide in rats. Asia Pac J Trop Med. 2011,4(6):475-477.

Parekh J, Chanda S. In-vitro antimicrobial activity and phytochemical analysis of some Indian medicinal plants. Turk J Biol. 2007,31(1):53-58.

Patel Y, Vadgama V, Baxi S, Tripathi B. Evaluation of hypolipidemic activity of leaf juice of Catharanthus roseus (Linn.) in guinea pigs. Acta Pol Pharm. 2011,68(6):927-935.
Ryan TH. Significance tests for multiple comparison of proportions, variances, and other statistics. Psychological Bulletin. 1960,57(4):318-328.

Rasineni K, Bellamkonda R, Singareddy SR, Desireddy S. Antihyperglycemic activity of Catharanthus roseus leaf powder in streptozotocin-induced diabetic rats. Pharmacog Res. 2010,2(3):195-201.

Sasidharan S, Chen Y, Saravanan D, Sundram KM, Latha LY. Extraction, isolation and characterization of bioactive compounds from plants' extracts. Afr J Tradit Complem Altern Med. 2011,8(1):1-10.

Tolambiya P, Mathur S. A study on potential phytopharmaceuticals assets in Catharanthus roseus L. Int J Life Sci Biotechnol Pharm Res. 2016,5(1):1-6.

Vega-Ávila E, Cano-Velasco JL, Alarcón-Aguilar FJ, Fajardo Ortíz MD, Almanza-Pérez JC, Román-Ramos R. Hypoglycemic activity of aqueous extracts from Catharanthus roseus. Evid.-based complement. altern. med. 2012,(1):1-7.

Received for publication on $31^{\text {st }}$ August 2018 Accepted for publication on $01^{\text {st }}$ February 2019 